Volume 5, Issue 2 (Summer 2013)

\title{
Rembrandt Looks to Schongauer
}

Nadine M. Orenstein

Recommended Citation:

Nadine M. Orenstein, “Rembrandt Looks to Schongauer” JHNA 5:2 (Summer 2013), DOI:10.5092/jhna.2013.5.2.10

Available at https://jhna.org/articles/rembrandt-looks-to-schongauer/

Published by Historians of Netherlandish Art: https://hnanews.org/

Republication Guidelines: https://jhna.org/republication-guidelines/

Notes: This PDF is provided for reference purposes only and may not contain all the functionality or features of the original, online publication. This is a revised PDF that may contain different page numbers from the previous version. Use electronic searching to locate passages. This PDF provides paragraph numbers as well as page numbers for citation purposes.

ISSN: 1949-9833 


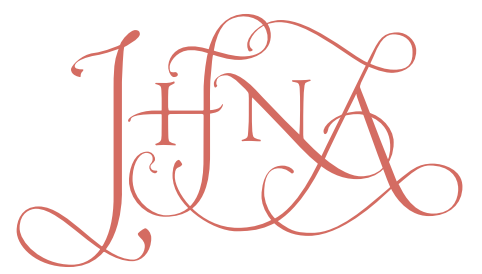

JOURNAL OF HISTORIANS OF NETHERLANDISH ART

\title{
REMBRANDT LOOKS TO SCHONGAUER
}

\author{
Nadine M. Orenstein
}

Rembrandt's use of works by earlier artists as formal inspiration for his own is well known. This essay examines Rembrandt's little-recognized appropriation of poses, compositions, and even methods of handling light and dark from Martin Schongauer's engraving Christ Carrying the Cross. Rembrandt returned to Schongauer's print at various moments in his career, most notably for the creation of one of his most ambitious etchings, The Hundred Guilder Print. 10.5092/ jhna.2013.5.2.10

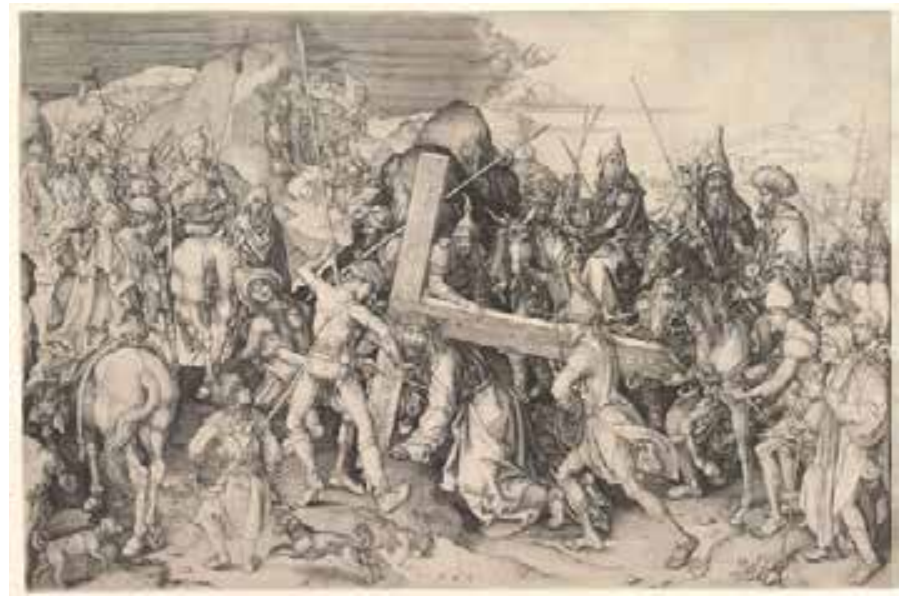

Fig. 1 Martin Schongauer, Christ Carrying the Cross, ca. 1475-80, engraving, $28.9 \mathrm{x}$ $42.9 \mathrm{~cm}$. The Metropolitan Museum of Art, New York, inv. no. 35.27 (artwork in the public domain) embrandt's use of works by earlier artists as formal inspiration for his own is well known. ${ }^{1}$ We often recognize in his drawings, prints, and paintings motifs from the Renaissance 1494-1533), and Andrea Mantegna (ca. 1431-1506), among others, as well as from works by such seventeenth-century artists as Jacques Callot (1592-1635) and Peter Paul Rubens (1577-1640). In contrast, works by fifteenth-century artists like Martin Schongauer (ca. 1420-1491), such as his masterpiece of early engraving, Christ Carrying the Cross (Lehrs 9) (fig. 1), with its nervous, animated drapery, unstable poses, and teetering setting, may be among the last pieces that come to mind when considering sources for Rembrandt's imagery. ${ }^{2}$ Peter Schatborn, however, 
recognized one instance in which Rembrandt turned to Schongauer for inspiration. Rembrandt looked at Christ Carrying the Cross for the figure of Christ in a drawing of the same subject in Berlin (Staatliche Museen, Kupferstichkabinette, inv. no. Kdz 1554). In that sheet, which dates to ca. 1635, Rembrandt took over the main motif and conceived a Christ upon hands and knees similarly weighed down by the cross. ${ }^{3}$ Rembrandt's inventory of 1656 indicates that he owned prints by Schongauer, so it would not be all that surprising to find that, on occasion, he would have drawn inspiration from works by his great predecessor in printmaking. ${ }^{4}$ This essay proposes that Rembrandt consulted Schongauer's work, and specifically the Christ Carrying the Cross, often and at various moments in his career. It also proposes that Rembrandt looked to this engraving not only for specific compositional motifs but also as a model for variations in handling and for strategizing the depiction of similar large multifigured compositions. It influenced most notably the creation of one of his most ambitious etchings, The Hundred Guilder Print, ca.1648 (Hollstein 74) (fig. 2). ${ }^{5}$

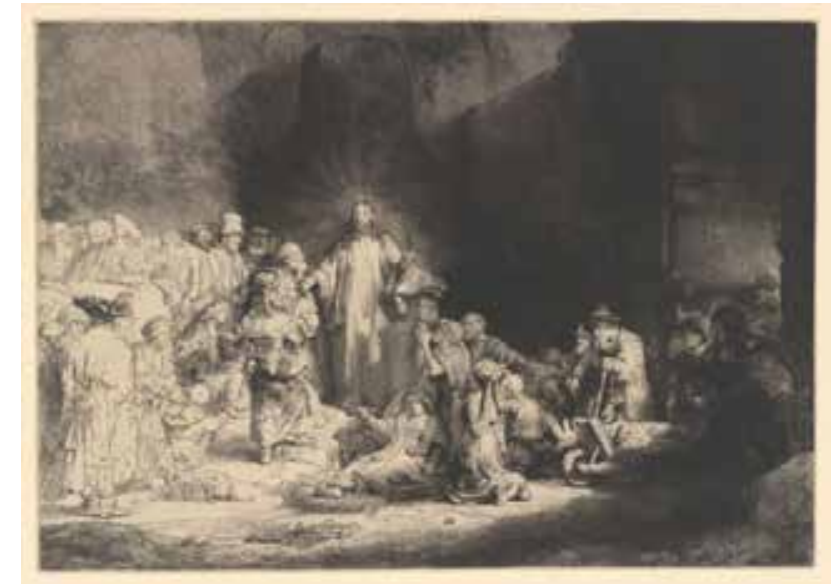

Fig. 2 Rembrandt van Rijn, The Hundred Guilder Print, ca. 1648, etching, engraving, and drypoint, second state of two, $28 \times 39.3 \mathrm{~cm}$. The Metropolitan Museum of Art, New York, inv. no. 29.107.35 (artwork in the public domain)

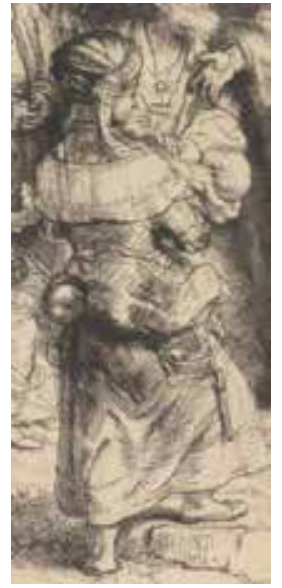

Fig. 3 Detail of Rembrandt van Rijn, The Hundred Guilder Print (fig. 2)

The Hundred Guilder Print is among Rembrandt's most engaging and complex compositions. The artist wove together individual episodes of the Gospel of St. Matthew to illustrate the entirety of chapter 19 in a horizontal format. He conceived an exquisite puzzle of darks against lights and lights against darks that draws the eye across the image. ${ }^{6}$ The figures progress into the composition from the area under the arch on the right toward the center, where Christ anchors the scene. Throughout the piece, the degree of handling shifts from figures in bright light, depicted in almost pure outline, to ones in shadow, heavily worked in etching and drypoint burr. Two states of the print exist, but the differences between them are minor. ${ }^{7}$ It is generally thought that Rembrandt worked on the etching over a period of several years. The many visible adjustments to figures and background, evident already in the first state, indicate that Rembrandt considered numerous variations to the image before the impressions of the currently recognized first state were printed. For instance, residual lines indicate that the man in the left background, who wears a skullcap was originally wearing a turban and his hand was raised (see fig. 10). Additionally, Christ's left arm, which was once pointed down, is now raised, and the woman carrying the baby in front of him was first positioned further to the right (fig. 3). Several drawings associated with the print have survived, and all of these relate to the group just to the right of Christ, but Rembrandt's thought 
process in assembling the rest of the image has remained unclear. ${ }^{8}$ Christopher White conceded that only a few generally relatable earlier sources have been identified, ranging from Leonardo to Annibale Carracci (1560-1609), as well as Lucas van Leyden. ${ }^{9}$ Schongauer's large and masterful Christ Carrying the Cross, however, offers more convincing evidence as a source for borrowing as he conceived the etching.

The clearest evidence for Rembrandt's reliance on Schongauer's engraving can be found in correspondences between figural and background motifs in both prints. Both display a boy viewed from the back with a dog at his feet at the bottom left. The stance of that boy in the Schongauer--upright, his feet turned out, one slightly in front of the other (fig. 4)--seems to have influenced the position of the feet of the turbanned woman holding a child on the left of Christ in Rembrandt's etching. She also turns her back to the viewer and stands with one foot bent in front of the other, her right arm crooked to cradle the infant. This woman can be seen, in fact, as having been inspired by two figures in the Schongauer, not only the small boy but also the man with a turban just to the right of Christ who bends his leg and arm in similar ways (fig. 5). Rembrandt seems to have also referenced the braid that emerges from the man's turban in the piece of cloth that falls from the woman's headdress. In another example, on the right of Rembrandt's etching an old blind man leaning on a stick is helped by a woman whose face appears slightly lower and to the far side of his (fig. 6). ${ }^{10}$ A parallel pairing can be found in Schongauer's print on the right, where a man leans on a walking stick and the head of a boy appears to his far side, just slightly lower than his head (fig. 7).

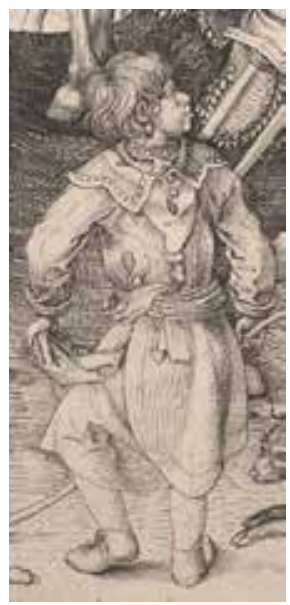

Fig. 4 Detail of Martin Schongauer, Christ Carrying the Cross (fig. 1)

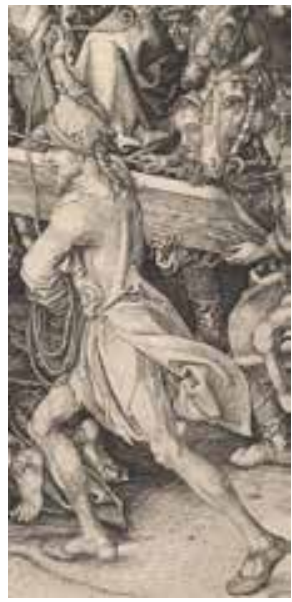

Fig. 5 Detail of Martin Schongauer, Christ Carrying the Cross (fig. 1)

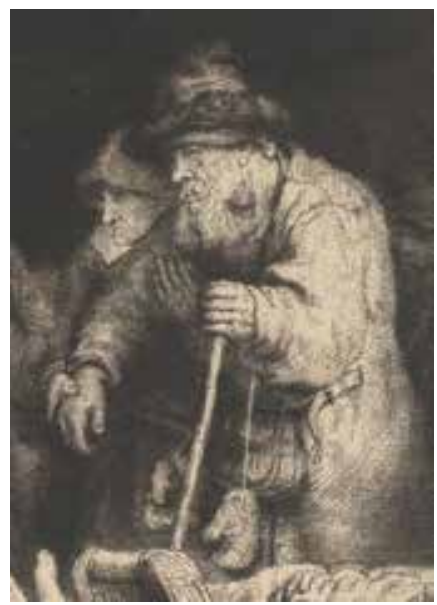

Fig. 6 Detail of Rembrandt van Rijn, The Hundred Guilder Print (fig. 2)

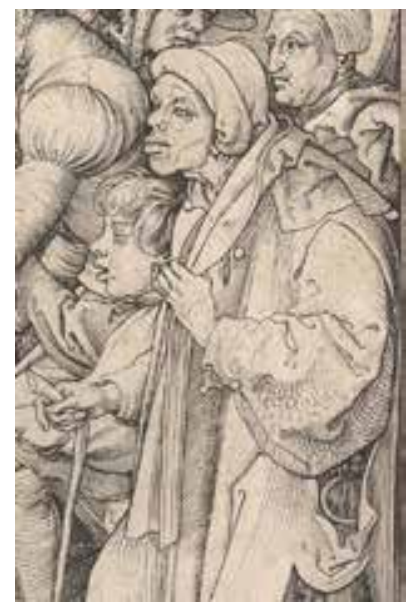

Fig. 7 Detail of Martin Schongauer, Christ Carrying the Cross (fig. 1)

4 This last example indicates that Rembrandt looked to Schongauer not merely as a resource for poses but also as a reference for ways of clustering figures within a larger mass. He created few compositions that include large numbers of figures. It should not be surprising to find that Rembrandt might have examined the work of earlier masters such as Schongauer to see how they might have handled similar compositional challenges.

5 The group of three Pharisees engaged in discussion in the left background of Rembrandt's etching 
suggests as well that he consulted Schongauer's engraving in just this way. The background group is composed of a row of men. The three main protagonists among them consist of a bearded man on the left wearing a skullcap, depicted in strict profile, who is in discussion with another man to the right, who sports a large beret and leans over as he turns his head toward the first. A third man, just to their right, bends over to listen in to their conversation. Ludwig Münz suggested with reason that two of the figures relate to a pair leaning on a ledge in the background of Lucas van Leyden's print The Adoration of the Magi (New Hollstein 37) (fig. 8) ${ }^{11}$ It seems quite likely, however, that the Schongauer was the initial source. Rembrandt's cluster of three men, two discussing and another looking on, corresponds in a general way to the three men on horseback in the upper right of Schongauer's print (fig. 9). There, we see, in reverse order, a bearded man wearing a turban in strict profile in discussion with another who sports a beard and a large pointed hood. To their left, another man turns to listen in on their conversation; in other words, the same combination of two men in conversation and a third listening.

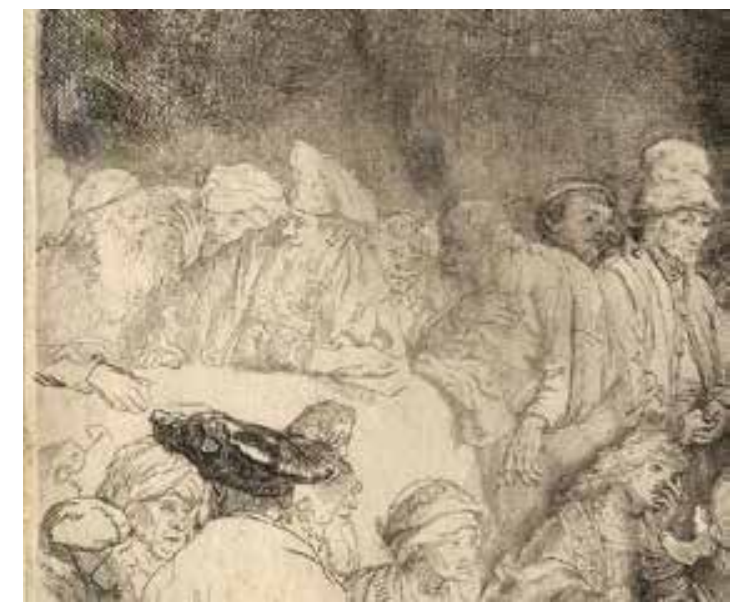

Fig. 10 Detail of Rembrandt van Rijn, The Hundred Guilder Print, ca. 1648, etching, engraving, and drypoint, second state of two, 28.1 x $39.5 \mathrm{~cm}$. The British Museum, London, inv. no. F, 7.5 (artwork in the public domain)

The connection between the figures in the Rembrandt and the Schongauer becomes more evident when we examine the print more closely. An early but unevenly inked impression of the second state in the British Museum allows a clear view of some of Rembrandt's pentimenti, which are often obscured in more richly printed ones (fig. 10)..$^{12}$ A careful examination of that impression reveals that Rembrandt's original conception for the profile figure with a skullcap was of a man wearing a large turban. Rembrandt changed his mind about the headdress and carefully hatched over the turban, the outline of which is visible in the first state of the print. The deleted turban relates the figure in profile to the corresponding one in Schongauer's engraving and, granted, also to the one in the Lucas print, both of whom wear turbans of slightly differing shapes. The large rounded shape of the turban that juts well past the forehead visible in the Rembrandt, however, comes closer to that in the Schongauer. Another detail points us to the German engraving as a source. As mentioned above, Rembrandt adjusted the gesture of this man's right hand at some point before he printed the first state. The initial raised position of the hand reflects that of the right hand of Schongauer's man in a turban. Rembrandt then redrew it so that the hand now points downward, much as in the man leaning on the ledge in Lucas's engraving. Perhaps he first 
turned to Schongauer for inspiration and then looked further to Lucas as he adjusted his initial conception.

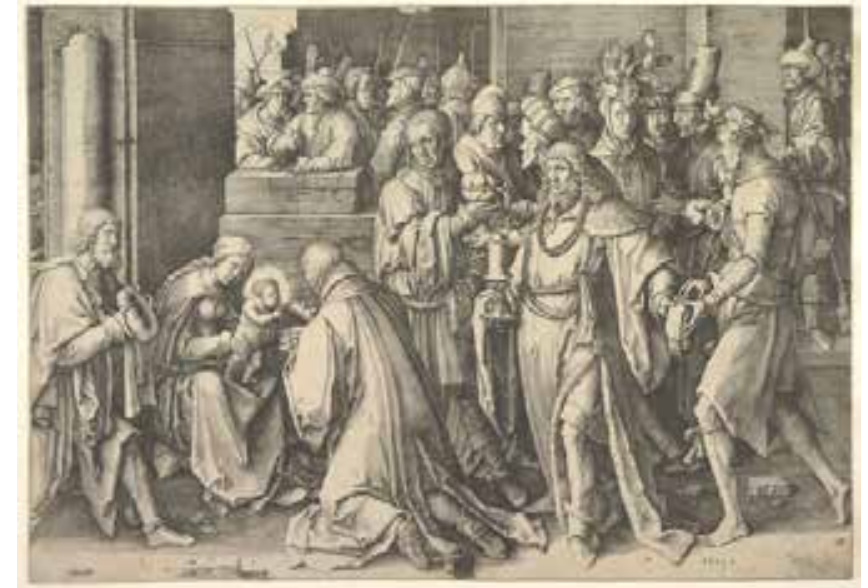

Fig. 8 Lucas van Leyden, The Adoration of the Magi, 1513, engraving, $30 \times 43.3$ $\mathrm{cm}$. The Metropolitan Museum of Art, New York, inv. no. 35.66 (artwork in the public domain)

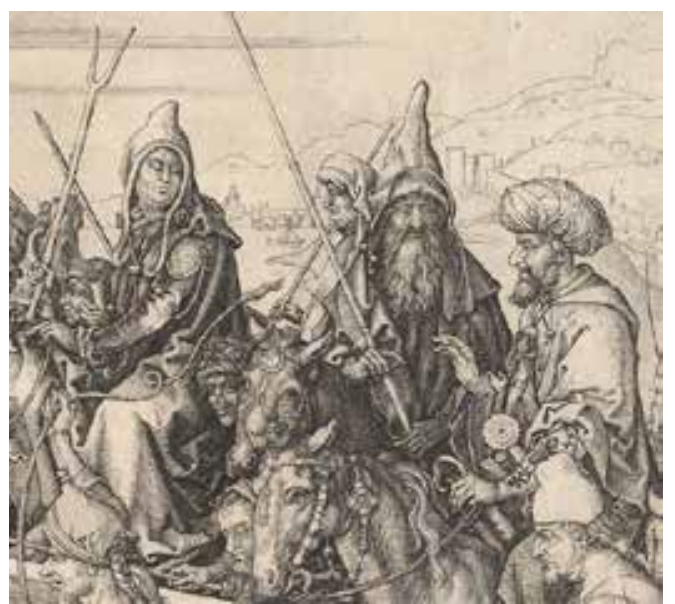

Fig. 9 Detail of Martin Schongauer, Christ Carrying the Cross (fig. 1)

7 One peculiar element that appears in The Hundred Guilder Print is the dark shape in the background behind Christ. This form is more or less the shape of a brimmed hat that is tall and flat in the center and juts out at the bottom on the right and left. Its role, aside from bringing further attention to Christ, is unclear. It does not have enough depth to be a cave and is a bit hard-edged to have been intended as a shadow, but what else it might be is not immediately evident. Its peculiar shape may have its roots in the Schongauer engraving. There, Christ is placed directly beneath some dark arched mountains that help to isolate and highlight this central figure within the bustling throng that surrounds him. This cluster of monoliths behind Christ in Schongauer's engraving, wide at the bottom and less so at the top and positioned substantially above Christ's head, seems to have been taken up by Rembrandt as a way of giving focus to his own figure of Christ. $^{13}$

Beyond the mere connections of figures and surroundings, Rembrandt's etching shares a more general compositional affinity with Schongauer's engraving. While the two prints differ in subject, their basic schemes are similar. Schongauer's engraving is a large horizontal image depicting a procession that moves from right to left. Despite the views into the distance, the entire scene is rather two-dimensional and close to the surface of the picture plane. Jam-packed with figures, it is anchored at its center by Christ, who draws the viewer's attention with his inescapable stare. Similarly, Rembrandt's etching depicts an assemblage of many figures, and the group on the right proceeds in from the side. It is likewise anchored by Christ at the center. Like Schongauer's scene, Rembrandt's also occupies primarily a single plane.

Furthermore, Schongauer's engraving can be viewed as a carefully mastered exercise in the alternation of darks and lights within a horizontal composition. The highly defined figures on horseback on the right are placed in front of an area of the sky and landscape that are defined merely by outline. In contrast, the figures in the background on the left are mainly created from outlines, and they are placed in front of the hatched section of the sky. And so it goes throughout the scene, 
densely hatched areas appear in front of less hatched ones, guiding the eye across the scene by means of this alternation. Rembrandt, clearly fascinated by effects of chiaroscuro from his earliest works, seems to have fixed on this element in Schongauer's print. In The Hundred Guilder Print, he created a similar alternation of juxtaposed dark and light areas. In the left background, the figures in bright light are delineated merely by outline placed against a dark background, while figures on the right are more densely hatched but set against areas of light. On the far right, where the dark figures proceed in through the archway, there is light coming in from behind them, and so forth. Describing figures in pure outline to suggest bright light is a method that we closely associate with Rembrandt, but it seems to have had its roots in the artist's study of Schongauer.

A closer look at the pentimenti suggests that Rembrandt might initially have been considering even more correspondences with Schongauer's print, which he later reconsidered. For instance, an examination of the scumbling in the lightly etched background on the left of The Hundred Guilder Print reveals a series of horizontal curves that have been etched over. Could they have once indicated a hilled landscape similar to the ones in the right and left backgrounds of Schongauer's engraving? Additionally, to the right of the dark shape above Christ, Rembrandt sketched some dangling branches with leaves. Their appearance and placement evoke the cluster of clouds that divides the dark and light areas of the sky in Schongauer's piece. Should this theory prove correct, one might read a certain degree of uncertainty on Rembrandt's part in this strong overall reliance on Schongauer's composition as he began to compose this large and complex print.

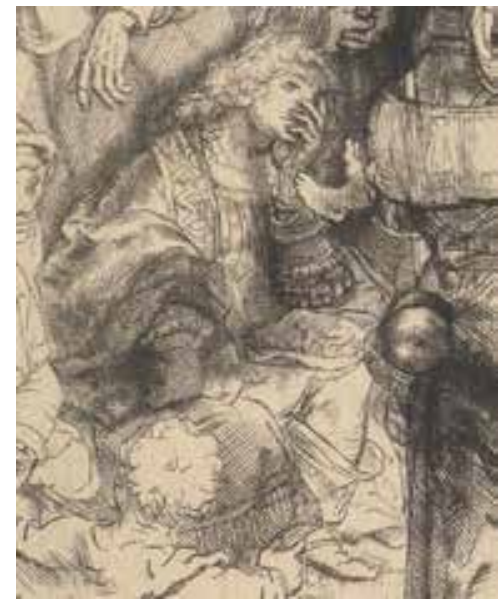

Fig. 11 Detail of Rembrandt van Rijn, The Hundred Guilder Print (fig. 2)

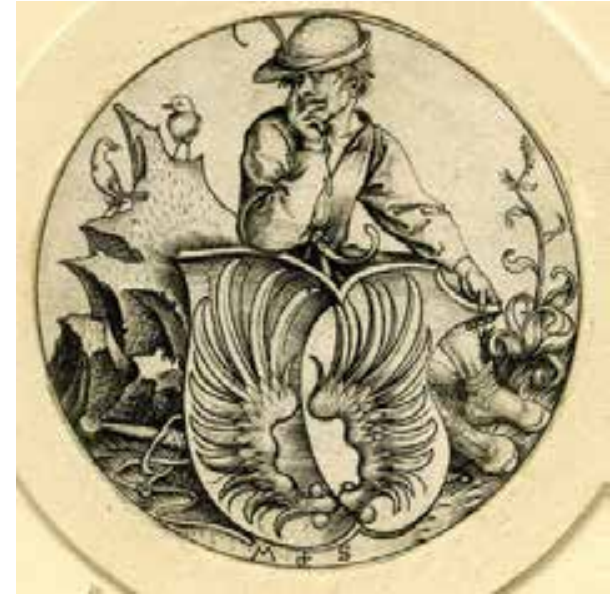

Fig. 12 Martin Schongauer, $A$ Shield with Wings Conjoined in Base, Supported by a Peasant, 1469-82, engraving diameter $7.3 \mathrm{~cm}$. The British Museum, London, inv. no. 1895,0915.293 (artwork in the public domain)

11 Rembrandt may have consulted one further print by Schongauer in delineating the pensive rich man on the left who questions whether to give up his riches to follow Christ (fig. 11). His pose, seated with his hand over his face, resembles in many ways that of Schongauer's peasant in $A$ Shield with Wings Conjoined in Base, Supported by a Peasant (Lehrs 101) (fig. 12). While Rembrandt's inventory does not reveal which specific prints by Schongauer were in his collection, he no doubt had several and it would have been natural for him to peruse the works housed together. 
12 A number of other pieces by Rembrandt show the influence of Schongauer's Christ Carrying the Cross. In the etching Abraham and Isaac, 1645 (Hollstein 34) (fig. 13) we find a turbanned Abraham in strict profile, raising his far hand in speech. His head with its beard turned up bears some resemblance again to the turbanned figure in profile on horseback who raises his far hand on the right of the Schongauer (see fig. 9). A possible relationship between these two prints becomes even more tantalizing if we compare the figure of Isaac sporting a pageboy haircut and a calf-length tunic to the boy with the dog in the bottom left of the Schongauer, who, while not identically posed, does display a similar haircut and dress (see fig. 4). The two figures in Schongauer's print are situated on opposite sides of the composition, yet their lines of sight are linked as though they are looking at each other, as the figures do more directly in the Abraham and Isaac. Here Rembrandt extracted a figural group of sorts from Schongauer and intensified their psychological interaction.

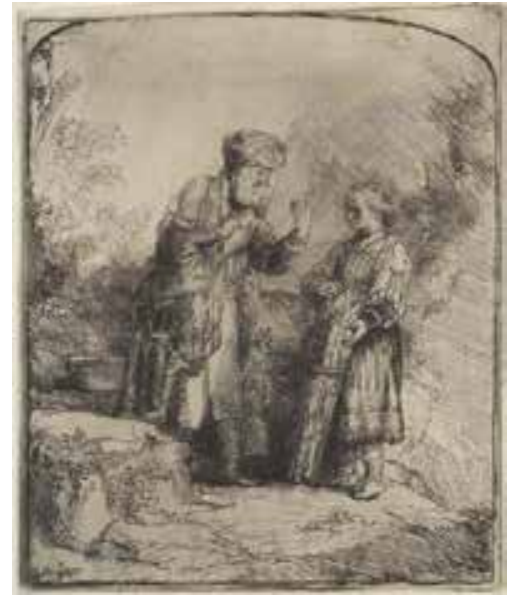

Fig. 13 Rembrandt van Rijn, Abraham and Isaac, 1645, etching and burin, $15.5 \times 13$ $\mathrm{cm}$. The Metropolitan Museum of Art, New York, inv. no. 29.107.26(artwork in the public domain)

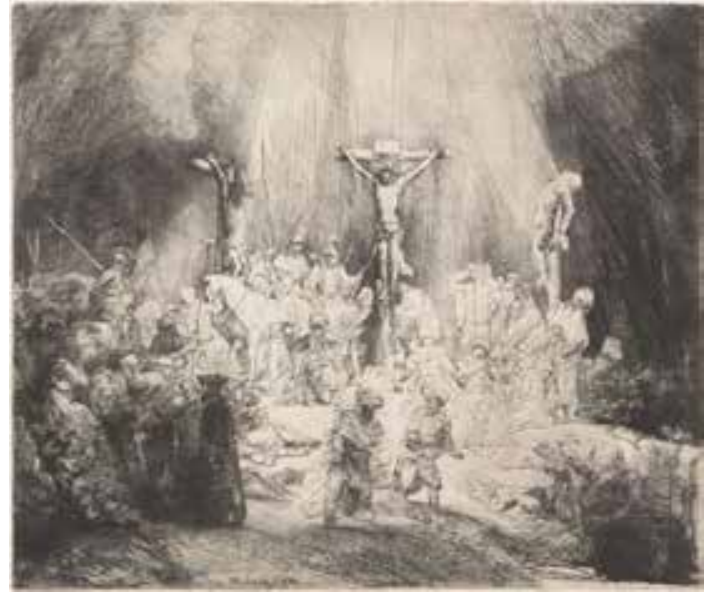

Fig. 14 Rembrandt van Rijn, Christ Crucified Between the Two Thieves (The Three Crosses), 1653, drypoint, third state of five, The Metropolitan Museum of Art, New York, inv. no. 41.1.32 (artwork in the public domain)

13 His next large multifigured print, Christ Crucified Between the Two Thieves (The Three Crosses), 1653 (Hollstein 78) (fig. 14), also relies on Schongauer. As in The Hundred Guilder Print, Rembrandt's treatment of figures here varies from those highly finished with hatching to those suggested merely by outlines. Furthermore, the soldiers on horseback with their spears raised to the left of the cross seem to have been loosely inspired by the figures on horseback on the right of Schongauer's print. In particular, the horse with a raised leg facing left in the Rembrandt group bears a strong resemblance in pose to the foremost horse among Schongauer's mounted horsemen. In addition, the group of figures gathered around the fainting Virgin to the right of the cross refers to a similar group around the fainting Mary in the far left background of Schongauer's print.

14 The works mentioned above all date to the 1640s, but there is evidence that Rembrandt looked at Schongauer much earlier as well. In addition to the drawing in Berlin touched upon at the start of this essay, there is the Sheet of Studies of Grieving Mary, 1635-36 (fig. 15) of about the same time, considered a study for Rembrandt's painted Entombment (Pinakothek, Munich). ${ }^{14}$ At the top of 


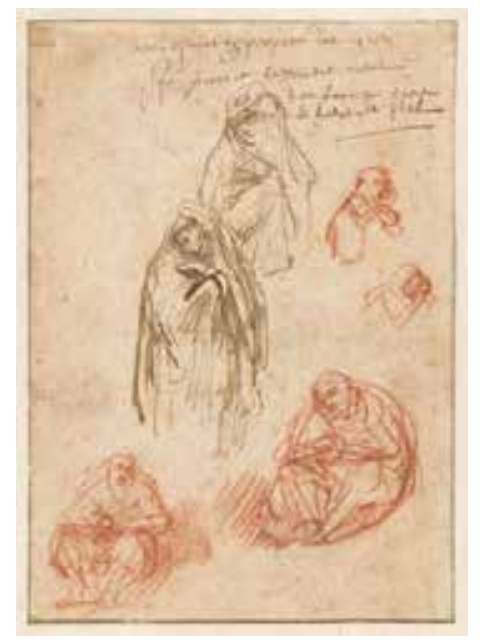

Fig. 15 Rembrandt van Rijn, Sheet of Studies of Grieving Mary, 1635-36, pen and brown ink and red chalk 20.1 x $14.3 \mathrm{~cm}$. Rijksmuseum, Amsterdam, inv. no. RP-T-1947-213 (artwork in the public domain)

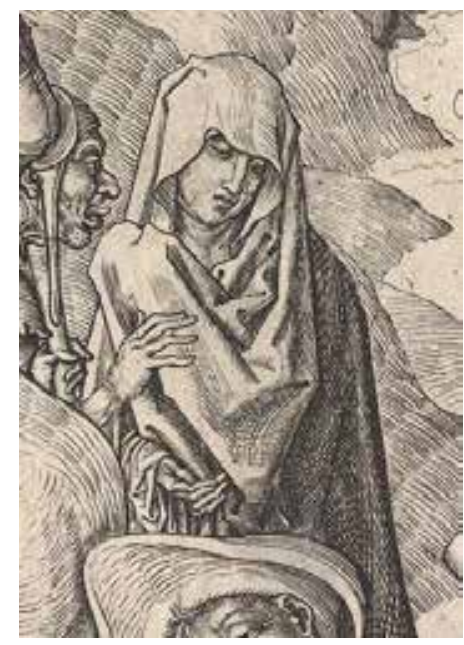

Fig. 16 Detail of Martin Schongauer, Christ Carrying the Cross (fig. 1)

the sheet are two figures of Mary drawn in brown ink. In both, she is wrapped in a cloak, which covers her head and one hand, and her head twists in the opposite direction of her body. This figure closely resembles in reverse Schongauer's Mary, who stands in the left background just to the right of the horse with a braided tail (fig. 16).

15 Another possible use of the Schongauer by Rembrandt, one that admittedly requires more of a leap than those mentioned above, may be found in his early etching, The Raising of Lazarus, ca. 1632 (fig. 17). In this print, Christ looms over the tomb with his back to the viewer, one arm raised on the far side of his head and the other arm bent at the waist, where a swathe of drapery gathers and billows behind him. This unusual pose, the far arm raised and the other arm bent, along with the swathe of drapery that waves behind, comes quite close to the figure of the man holding a rope just to the right of Christ in Schongauer's print see fig. 5). If this connection is correct, it may add a further piece of evidence to the discussion of the ordering of several related works, the painting and etching by Jan Lievens and Rembrandt's painting of the same subject (Los Angeles County Museum of Art) ${ }^{15}$ Rembrandt's painting depicts Christ with one hand raised and the other on his hip but viewed facing forward. Could the etching predate the painting?

16 Whether one accepts this last example or not, it is clear that, from a relatively early point in his career, Rembrandt consulted Schongauer's work, and specifically Christ Carrying the Cross, and that the print continued to interest him over several decades. This should hardly be surprising, as it was one of the great masterpieces of printmaking which preceded him. It offered a wonderful array of figures in oriental costume that must have appealed to Rembrandt as he created his own biblical scenes. Yet, he did not so much look to Schongauer for exotic costumes as he did for poses, compositional ideas, and methods of handling light and dark in print. These borrowings were meant as blueprints, starting points, which Rembrandt would rethink and redraw as he further considered the composition. In early work, his use of sources seems to have focused on 


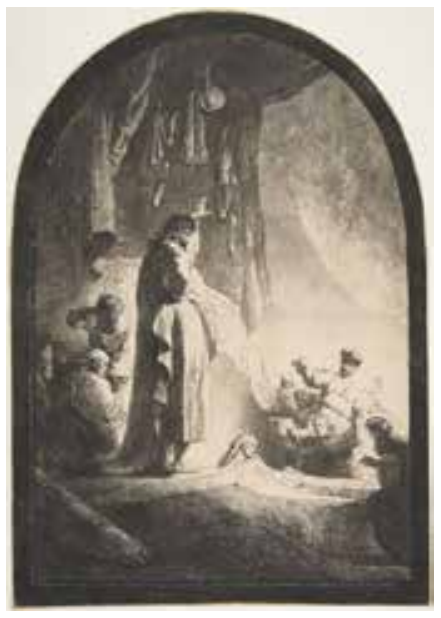

Fig. 17 Rembrandt van Rijn, The Raising of Lazarus: The Larger Plate, ca. 1632, etching and burin, $36.8 \times 25.5 \mathrm{~cm}$. The Metropolitan Museum of Art, New York, inv. no. 17.37 .194 (artwork in the public domain)

specific poses and he chose sources that related in subject to the work that he was in the process of creating, while in later ones he was intrigued instead by general compositional solutions to be found in the engraving, such as the dispersal of light and dark and methods of clustering and interrelating figures. Schongauer's lightweight, unsteady figures full of Gothic movement at first hardly seem the stuff to have inspired Rembrandt's solid figures seemingly based on everyday life studies. Yet this image, chock-full of exotic people both rich and poor, who noisily interact with each other, seems to have spoken to Rembrandt's own artistic interests at various stages in his career. No doubt further references to Schongauer's print within his oeuvre can be identified, and they should reveal more about Rembrandt's borrowings from unexpected works and how his close study of earlier masters infused his own art. ${ }^{16}$

\section{Acknowledgements}

Some of my most valuable learning experiences at the Institute of Fine Arts under Egbert Haverkamp-Begemann's tutelage took place outside the classroom: on visits with him to private collectors, auctions houses, and dealers. The idea for this essay, which came to me as I was laying out prints on the Metropolitan Museum's print study room table for a class that I was about to teach, is indebted to those memorable visits, which always underscored the fact that examining real works of art is of the utmost importance.

Nadine M. Orenstein, Curator in The Metropolitan Museum's Department of Drawings and Prints. Her Ph.D. dissertation (IFA 1992) was published as Hendrick Hondius and the Business of Prints in Seventeenth-Century Holland. Her exhibitions include Pieter Bruegel the Elder: Drawings and Prints and Hendrick Goltzius (1558 - 1617) Prints, Drawings and Paintings.

\section{List of Illustrations}

Fig. 1 Martin Schongauer, Christ Carrying the Cross, ca. 1475-80, engraving, 28.9 x $42.9 \mathrm{~cm}$. The Metropolitan Museum of Art, New York, inv. no. 35.27 (artwork in the public domain) 
Fig. 2 Rembrandt van Rijn, The Hundred Guilder Print, ca. 1648, etching, engraving, and drypoint, second state of two, 28 x $39.3 \mathrm{~cm}$. The Metropolitan Museum of Art, New York, inv. no. 29.107.35 (artwork in the public domain)

Fig. 3 Detail of Rembrandt van Rijn, The Hundred Guilder Print (fig. 2)

Fig. 4 Detail of Martin Schongauer, Christ Carrying the Cross (fig. 1)

Fig. 5 Detail of Martin Schongauer, Christ Carrying the Cross (fig. 1)

Fig. 6 Detail of Rembrandt van Rijn, The Hundred Guilder Print (fig. 2)

Fig. 7 Detail of Martin Schongauer, Christ Carrying the Cross (fig. 1)

Fig. 8 Lucas van Leyden, The Adoration of the Magi, 1513, engraving, 30 x $43.3 \mathrm{~cm}$. The Metropolitan Museum of Art, New York, inv. no. 35.66 (artwork in the public domain)

Fig. 9 Detail of Martin Schongauer, Christ Carrying the Cross (fig. 1)

Fig. 10 Detail of Rembrandt van Rijn, The Hundred Guilder Print, ca. 1648, etching, engraving, and drypoint, second state of two, 28.1 x $39.5 \mathrm{~cm}$. The British Museum, London, inv. no. F, 7.5 (artwork in the public domain)

Fig. 11 Detail of Rembrandt van Rijn, The Hundred Guilder Print (fig. 2)

Fig. 12 Martin Schongauer, A Shield with Wings Conjoined in Base, Supported by a Peasant, 146982, engraving diameter $7.3 \mathrm{~cm}$. The British Museum, London, inv. no. 1895,0915.293 (artwork in the public domain)

Fig. 13 Rembrandt van Rijn, Abraham and Isaac, 1645, etching and burin, $15.5 \mathrm{x} 13 \mathrm{~cm}$. The Metropolitan Museum of Art, New York, inv. no. 29.107.26(artwork in the public domain)

Fig. 14 Rembrandt van Rijn, Christ Crucified Between the Two Thieves (The Three Crosses), 1653, drypoint, third state of five, The Metropolitan Museum of Art, New York, inv. no. 41.1.32 (artwork in the public domain)

Fig. 15 Rembrandt van Rijn, Sheet of Studies of Grieving Mary, 1635-36, pen and brown ink and red chalk 20.1 x $14.3 \mathrm{~cm}$. Rijksmuseum, Amsterdam, inv. no. RP-T-1947-213 (artwork in the public domain)

Fig. 16 Detail of Martin Schongauer, Christ Carrying the Cross (fig. 1)

Fig. 17 Rembrandt van Rijn, The Raising of Lazarus: The Larger Plate, ca. 1632, etching and burin, 36.8 x $25.5 \mathrm{~cm}$. The Metropolitan Museum of Art, New York, inv. no. 17.37.194 (artwork in the public domain) 
${ }^{1}$ B. P. J. Broos, Index to the Formal Sources of Rembrandt's Art (Maarssen: Gary Schwartz, 1977) and Ben [B. P. J.] Broos, "Rembrandt and His Picturesque Universe: The Artist's Collection as a Source of Inspiration," in Rembrandt's Treasures, ed. Bob van den Boogert, exh. cat. (Amsterdam: Rembrandt House Museum / Zwolle: Waanders Publishers, 1999), 91-139. My thanks to An van Camp, Erik Hinterding, Martin Royalton-Kisch, and Elizabeth Eisenberg.

${ }^{2}$ Ben Broos in his compilation of Rembrandt's sources noted references to Rembrandt's reliance on Schongauer in two etchings by the master The Flight into Egypt: A Sketch (Hollstein 54), loosely indebted to the Colmar printmaker's The Flight into Egypt (Lehrs 7), and more convincingly The Death of the Virgin (Hollstein 99), which is reliant on the earlier Death of the Virgin (Lehrs 16). He also mentioned a drawing, Christ Carrying the Cross (Teylers Museum Haarlem), now tentatively attributed to Willem Drost, that was likely inspired by Schongauer's Christ Carrying the Cross; see Michiel C. Plomp, The Dutch Drawings in the Teyler Museum (Haarlem, Ghent, and Doornspijk: Teyler Museum, Snoeck Ducaju \& Zoon, and Davaco Publishers,1997), vol. 2, no. 117. The references to Schongauer's prints will be given here with Lehrs numbers, referring to Max Lehrs, Geschichte und kritischer Katalog des Deutschen, Niederländischen und Französichen Kupferstichs im XV Jahrhundert, vol. 5 (Vienna: Gesellschaft für Vervielfältigende Kunst, 1925). ${ }^{3}$ Peter Schtaborn in Holm Bevers, Peter Schatborn, and Barbara Welzel, Rembrandt: The Master and His Workshop: Drawings and Etchings (New Haven and London: Yale University Press in association with London National Gallery Publications, 1991), 35-36; and Holm Bevers, Rembrandt: Die Zeichnungen im Berliner Kupferstichkabinett: Kritischer Katalog (Ostfildern: Hatje Cantz, 2006), 47-49.

4 "237. Een papiere kas vol printen van Hubse Marten, Holbeen, Hans Broesmer en Israel van Ments.": Rembrandt's inventory (1656), Gemeentearchief Amsterdam, arch. no. 5072, inv. no. 364, fol. 29-38 v, dd July 25 and 26, 1656, cited in Appendix 2 in Rembrandt's Treasures, 147-52. Schongauer was known starting in the fifteenth century as Hübsch Martin.

${ }^{5}$ The references for the Rembrandt prints mentioned here will be given with Hollstein numbers, referring to Christopher White and Karel G. Boon, Rembrandt van Rijn, vol. 18 of Hollstein's Dutch and Flemish Etchings, Engravings and Woodcuts (Amsterdam: Van Gendt \& Co., 1969). ${ }^{6}$ On this print, see Christopher White, Rembrandt as an Etcher: A Study of the Artist at Work, 2nd ed. (New Haven and London: Yale University Press, 1999), 54-64; and Martin Royalton-Kisch in Rembrandt the Printmaker, by Erik Hinterding, Ger Luijten, and Martin Royalton-Kisch (Amsterdam: Rijksmuseum and Zwolle: Waanders, 2000), 253-58.

${ }^{7}$ According to White and Boon (Hollstein, n. 5), in the second state parallel shading was added to the neck of the ass and the burr of the drypoint in the center was either scraped away or worn down.

${ }^{8}$ White, Rembrandt, 57-62. I would argue that the drawing in the Louvre (Benesch 543; White, Rembrandt, fig. 75; Martin Royalton-Kisch in Rembrandt the Printmaker, no.6), the authenticity of which has been questioned, and which is usually considered to be a study for the group to the left of Christ, relates more closely to the group on the right because a number of the same figures which appear in the other sketches for that group appear here as well, namely the woman with two strips of cloth hanging down her back who is kneeling, the old bearded man with a fur cap, and the young bearded man who is crouching here but standing in the center of the drawing in Berlin (Benesch 188; White, Rembrandt, fig. 70); in addition, Christ's arm in the Louvre drawing is raised in their direction as it is in the final version of the print.

${ }^{9}$ White, Rembrandt, 57n6; Ludwig Münz discussed these sources in A Critical Catalogue of 
Rembrandt's Etchings and the Etchings of His School Formerly Attributed to the Master (London: Phaidon Press, 1952), 1:101. Jan Veth rightly found connections with Lucas van Leyden's painting Healing the Blind Man of Jericho in the Hermitage Museum, St. Petersburg; see Veth, "Rembrandts zoogenaamde Jodenbruid uit de kollektie Van der Hoop," Oud Holland 24 (1906): 42-43.

${ }^{10}$ A drawing for this figure, Blind Old Man Guided by a Woman exists in the Louvre, but there the woman is looking at him and her body is in a different position relative to the man.

${ }^{11}$ Jan Piet Filedt Kok et al., The New Hollstein Dutch and Flemish Etchings, Engravings and Woodcuts 1450-1700: Lucas van Leyden (Rotterdam: Sound \& Vision Interactive, 1996). Münz disagreed with Veth's connection of the Pharisees with Lucas van Leyden's painting in the Hermitage (see note 9 above); see Münz, Critical Catalogue, no. 9.

${ }^{12}$ Inventory number F, 7.5. The impression is less inked in some areas and overly inked in others; horizontally through the center there is a band with ink striations which seems to have been produced by the artist swiping a stiff, ink-laden rag across the plate. Oddly enough, this band of ink corresponds quite closely to the placement of the horizontal section of the cross in Schongauer's print and the marked texture of that swipe of ink also evokes the remarkable texture of Schongauer's cross. Might this have been an intentional reference to the Schongauer?

${ }^{13}$ The shape of the combined easel and canvas in the first state of Rembrandt's Portrait of Jan Asselijn (Hollstein 277) of about the same time bears a similar shape; my thanks to Stephanie Dickey for pointing out this resemblance.

${ }^{14}$ Peter Schatborn, Dutch Figure Drawings from the Seventeenth Century (The Hague: Government publishing office, 1981), 54-55, cat. 82.

${ }^{15}$ On the question of the dating see J. Bruyn et al., A Corpus of Rembrandt Paintings (The Hague and Boston: Martinus Nijhoff, 1982-89), 1:300-306; and Gary Schwartz, Rembrandt, His Life, His Paintings (New York: Viking, 1985), 83-86.

${ }^{16}$ Further references to the engraving may still be found; other possibilities that I have not had time to thoroughly consider here include The Triumph of Mordechai (Hollstein 40) and the mounted soldier in The Baptism of the Eunuch (Hollstein 98).

\section{Bibliography}

Benesch, Otto. The Drawings of Rembrandt, Enlarged and Edited by Eva Benesch. 6 vols. London: Phaidon, 1954-47. Enlarged edition, 1973.

Bevers, Holm, Peter Schatborn, and Barbara Welzel. Rembrandt: The Master and His Workshop; Drawings and Etchings. New Haven and London: Yale University Press in association with London National Gallery Publications, 1991.

Bevers, Holm. Rembrandt: Die Zeichnungen im Berliner Kupferstichkabinett: Kritischer Katalog. Ostfildern: Hatje Cantz, 2006.

Broos, B. P. J. Index to the Formal Sources of Rembrandt's Art. Maarssen: Gary Schwartz, 1977.

Broos, Ben [B. P. J.]. "Rembrandt and His Picturesque Universe: The Artist's Collection as a Source of Inspiration.” In Rembrandt's Treasures, edited by Bob van den Boogert, 91-139. Exh. cat. Amsterdam: Rembrandt House Museum / Zwolle: Waanders Publishers, 1999. 
Bruyn, J., et al. A Corpus of Rembrandt Paintings. 3 vols. The Hague and Boston: Martinus Nijhoff, 1982-89.

Filedt Kok, Jan Piet, et al. The New Hollstein Dutch and Flemish Etchings, Engravings and Woodcuts 1450-1700: Lucas van Leyden. Rotterdam: Sound \& Vision Interactive, 1996.

Hinterding, Erik, Ger Luijten, and Martin Royalton-Kisch. Rembrandt the Printmaker. Amsterdam: Waanders Publishers and Rijksmuseum Amsterdam, 2000.

Lehrs, Max. Geschichte und kritischer Katalog des Deutschen, Niederländischen und Französichen Kupferstichs im XV Jahrhundert. 9 vols. Vienna: Gesellschaft für Vervielfältigende Kunst, 1908-34.

Münz, Ludwig. A Critical Catalogue of Rembrandt's Etchings and the Etchings of His School Formerly Attributed to the Master. 2 vols. London: Phaidon Press, 1952.

Plomp, Michiel C. The Dutch Drawings in the Teyler Museum. Haarlem, Ghent, and Doornspijk: Teyler Museum, Snoeck Ducaju \& Zoon, and Davaco Publishers, 1997.

Rembrandt's Treasures. Edited by Bob van den Boogert. Exh. cat. Amsterdam: Rembrandt House Museum / Zwolle: Waanders Publishers, 1999.

Schatborn, Peter. Dutch Figure Drawings from the Seventeenth Century. The Hague: Government publishing office, 1981.

Schwartz, Gary. Rembrandt, His Life, His Paintings. New York: Viking, 1985.

Veth, Jan. "Rembrandts zoogenaamde Jodenbruid uit de kollektie Van der Hoop." Oud Holland 24 (1906): 41-44.

White, Christopher. Rembrandt as an Etcher: A Study of the Artist at Work. 2nd ed. New Haven and London: Yale University Press, 1999.

White, Christopher, and Karel G. Boon. Rembrandt van Rijn. Vol. 18 of Hollstein's Dutch and Flemish Etchings, Engravings and Woodcuts. Amsterdam: Van Gendt \& Co., 1969.

Recommended Citation:

Nadine M. Orenstein, "Rembrandt Looks to Schongauer," JHNA 5:2 (Summer 2013), D0I: 10.5092/jhna.2013.5.2.10 